\title{
Influence of intrinsic sympathomimetic activity on respiratory function during chronic $\beta$ blockade: comparison of propranolol and pindolol
}

\author{
R J NORTHCOTE， D BALLANTYNE
}

\begin{abstract}
The long term effect of $\beta$ blockers and the influence of intrinsic sympathomimetic activity on respiratory function were assessed in patients with chronic stable angina pectoris randomised to receive treatment with propranolol $(n=21)$ or pindolol $(n=19)$ for one year. Forced expiratory volume in one second $\left(F E V_{1}\right)$ had fallen by a mean of $240 \mathrm{ml}$ after one year $(p<0.001)$ in those treated with propranolol compared with $120 \mathrm{ml}$ in those treated with pindolol $(p<0.05)$. The difference between the groups was significant $(p<0.01)$. Vital capacity fell significantly only in those treated with propranolol $(\mathrm{p}<\mathbf{0 . 0 5}$ at one year). In those in whom the basal ratio of $\mathrm{FEV}_{1}$ to forced vital capacity was low $(<70 \%)$ propranolol, but not pindolol, caused a significant $(p<0.05)$ fall in FEV $_{1}$ throughout treatment.

Long term administration of pindolol has a less adverse effect on respiratory function than propranolol, which results in a progressive deterioration in respiratory function over one year.
\end{abstract}

\section{Introduction}

$\beta$ Blockers may have a deleterious effect on respiratory function owing to blockade of the $\beta$ adrenoceptors in the lung, which are responsible for bronchomotor tone; this results in appreciable bronchoconstriction in susceptible subjects, such as those with chronic obstructive airways disease, in whom the use of $\beta$ blockers may be restricted, ${ }^{12}$ and patients with asthma. ${ }^{2-4}$ Furthermore, acute bronchospasm may occur in some subjects with no history of asthma, chronic obstructive airways disease, or allergic disorders. ${ }^{56}$ Some $\beta$ blockers cause an increase in airways resistance in healthy subjects.' Using a body plethysmograph, MacDonald et al and $\mathrm{McNeill}$ and Ingram showed that a single dose of intravenous propranolol may increase airway resistance. ${ }^{89}$

Department of Medical Cardiology, Victoria Infirmary, Glasgow G42 9TY R J NORTHCOTE, MD, MRCP, senior registrar in medicine and cardiology D BALLANTYNE, MD, FRCPGLAS, consultant physician and cardiologist

Correspondence to: Dr Northcote.
Propranolol, a non-selective $\beta$ blocker without intrinsic sympathomimetic activity, is the $\beta$ blocker most commonly incriminated as having such respiratory effects. ${ }^{2+}$ Few studies have reported the long term effect of propranolol on patients with non-asthmatic chronic obstructive airways disease, and the results have been conflicting. ${ }^{10.12}$ Most controlled studies have been based on single doses of $\beta$ blocker given either intravenously or orally. ${ }^{13-15}$ Data on long term treatment have usually resulted from open, uncontrolled investigations, ${ }^{1617}$ and so its effect has not been established. $\beta$ Blockers with intrinsic sympathomimetic activity are thought to have a less detrimental effect on ventilation compared with "pure" $\beta$ blockers, such as propranolol. The role of intrinsic sympathomimetic activity in moderating bronchoconstriction induced by $\beta$ blockers, however, is not clear. ${ }^{18}$ We undertook this study to establish the effect of long term oral administration of $\beta$ blockers on respiratory function in a group of patients with angina pectoris and to assess the potential benefits of intrinsic sympathomimetic activity.

\section{Patients and methods}

Forty consecutive men with chronic stable angina (New York Heart Association class II or III) were recruited to the study from a cardiac clinic. A diagnosis of reversible myocardial ischaemia was confirmed by exercise electrocardiography. Patients were excluded if they suffered from reversible airways obstruction, a known allergic disorder, diabetes mellitus, heart block, or renal failure. Before recruitment the patients either had been responding inadequately to treatment or had not been receiving any. All treatment was withdrawn over two weeks, and after a further two weeks without taking any drugs the patients were randomly allocated on a single blind basis to treatment with propranolol $40 \mathrm{mg}$ thrice daily $(\mathrm{n}=21)$ or pindolol $2.5 \mathrm{mg}$ thrice daily $(\mathrm{n}=19)$ for two weeks, the dosages increasing thereafter to $80 \mathrm{mg}$ and $5 \mathrm{mg}$, respectively, thrice daily. The drugs were formulated as indistinguishable opaque gelatin capsules. Glyceryl trinitrate was the only other routine drug permitted throughout the study.

Respiratory function was assessed two, six, 12, 26, and 52 weeks after the start of treatment and results analysed without knowledge of the drug being taken. Airways diameter was estimated indirectly by measuring forced vital capacity (FVC) and forced expiratory volume in one second $\left(\mathrm{FEV}_{1}\right)$ with a Morgan rolling seal dry spirometer (model b), which has a reproducibility better than $2 \%$; the resultant ratio of $\mathrm{FEV}_{1}$ : FVC was then 
calculated. All measurements were taken after the patients had rested seated for three minutes after an overnight fast. Measurements were taken at 09301100 , two to three hours after the last oral dose of $\beta$ blocker, as this is the time when peak blood concentrations occur. ${ }^{19}$ On each occasion the patient had been present in the laboratory for at least 45 minutes to allow for equilibration to occur. There is no consensus over the number of measurements of each variable that need be taken when measuring respiratory function. ${ }^{20}$ In the present study we used the mean of three satisfactory attempts after a single training attempt, each attempt being separated by one minute. The spirometer was calibrated daily, before any measurement. As a dry spirometer was used the volumes indicated on the chart paper were corrected to standard temperature and pressure according to the ambient temperature.

Statistical analysis-For each variable changes within the groups were assessed by two way analysis of variance. If the $\mathrm{F}$ value obtained indicated a significant change post hoc comparisons were made using Student's paired $t$ test and a Wilcoxon signed rank test (for non-normally distributed data), comparing values at two, six, 12 , and 52 weeks with basal values. Differences between the groups were tested using both Student's unpaired $t$ test and a Mann-Whitney test. The most conservative significance values from these tests are reported.

\section{Results}

The two groups of patients were similarly matched in terms of age, body weight, height, and mass index (table I). Table II shows the results of

TABLE I-Characteristics of patients recorded at first hosplıal visit, before treatment. (Values expressed as means (SD) or as numbers (\%) of patients)

\begin{tabular}{|c|c|c|c|}
\hline & $\begin{array}{l}\text { Patients receiving } \\
\text { pindolol }(n=19)\end{array}$ & $\begin{array}{l}\text { Patients receiving } \\
\text { propranolol }(n=21)\end{array}$ & $\begin{array}{c}\mathrm{p} \\
\text { Value }\end{array}$ \\
\hline Age (years) & $54 \cdot 1 \quad(9 \cdot 75)$ & $52 \cdot 8 \quad(5 \cdot 95)$ & NS \\
\hline Quetelet index $\left(\times 10^{3}\right)\left(\mathrm{kg} / \mathrm{cm}^{2}\right)$ & $2.45(0.30)$ & $2.49(0.29)$ & NS \\
\hline Height $(\mathrm{m})$ & $1.75(0.07)$ & $1.74(0.06)$ & NS \\
\hline Weight (kg) & $75 \cdot 2 \quad(9 \cdot 96)$ & $75 \cdot 1(10 \cdot 42)$ & NS \\
\hline Heart rate (beats $/ \mathrm{min}$ ) & $(8 \cdot 6)$ & $(10 \cdot 3)$ & NS \\
\hline Systolic blood pressure $(\mathrm{mm} \mathrm{Hg})$ & $(17 \cdot 7)$ & $(28 \cdot 8)$ & NS \\
\hline Diastolic blood pressure $(\mathrm{mm} \mathrm{Hg})$ & $(13 \cdot 9)$ & $(15 \cdot 0)$ & NS \\
\hline No $(\%)$ of current smokers $(\geqslant 10 /$ day $)$ & (37) & $(38)$ & \\
\hline No $(\%)$ of ex-smokers & (42) & (24) & \\
\hline $\begin{array}{l}\text { No (\%) with previous myocardial } \\
\text { infarction }\end{array}$ & (32) & (29) & \\
\hline
\end{tabular}

respiratory function tests. Basal respiratory function was similar in the two groups, although those taking propranolol had a slightly lower FEV 1 (NS).

In those treated with pindolol mean $\mathrm{FEV}_{1}$ had fallen by $120 \mathrm{ml}$ after 52 weeks' treatment $(\mathbf{p}<0.05)$. When results were expressed as a percentage of the value predicted for age (using nomograms $\mathrm{s}^{21}$ ) there was a highly significant fall in mean $\mathrm{FEV}_{1}$, from $89.5 \%$ to $85.6 \%$ at 52 weeks $(\mathrm{p}<0.01)$ No significant changes occurred in other variables, although the ratio of $\mathrm{FEV}_{1}$ :FVC fell slightly, reflecting the fall in $\mathrm{FEV}_{1}$.

In those treated with propranolol the fall in $\mathrm{FEV}_{1}$ was significant at two weeks $(p<0.05)$ and increased sequentially to a mean of $240 \mathrm{ml}$ at 52 weeks $(p<0.001)$. A similar significant reduction occurred when $F_{E V}$ was expressed as a percentage of the predicted value. A significant fall in FVC occurred at 52 weeks $(p<0.05)$, and although the ratio of $F E V_{1}: F V C$ did not change this reflected similar decreases in $\mathrm{FEV}_{1}$ and FVC. The difference in the mean fall in $\mathrm{FEV}_{1}$ at 52 weeks achieved with pindolol compared with propranolol $(127 \vee 241 \mathrm{ml})$ reached significance $(\mathrm{p}<0.01)$ (table III). Similarly, the fall in FVC in patients taking propranolol was significantly greater $(\mathrm{p}<0.01)$ at 26 and 52 weeks than that in patients taking pindolol, although the resultant change in $\mathrm{FEV}_{1}: \mathrm{FVC}$ ratio was not significantly different.

Pindolol caused a significant reduction in $\mathrm{FEV}_{1}$ and $\mathrm{FEV}_{1}: \mathrm{FVC}$ at 52 weeks only when the basal value of $\mathrm{FEV}_{1}: \mathrm{FVC}$ was $70 \%$ or more (table IV). Propranolol caused a similar reduction in $\mathrm{FEV}_{1}$ regardless of whether the basal value was less or greater than $70 \%$, although the reduction was more significant at 12 and 52 weeks in those with basal ratios of $70 \%$ or more.

TABLE III-Mean reductions in $F E V_{l}$ compared with basal values

\begin{tabular}{lccccc}
\hline & \multicolumn{5}{c}{ Weeks after start of treatment } \\
\cline { 2 - 6 } & $2 \dagger$ & $6 \dagger$ & $12 \dagger$ & $26 \dagger$ & $52 \dagger$ \\
\hline Pindolol & 52 & 55 & 99 & 92 & $127^{\star}$ \\
Propranolol & $134^{\star}$ & $171^{\star}$ & $211^{\star \star \star}$ & $208^{\star \star}$ & $241^{\star \star \star}$
\end{tabular}

Difference within group: ${ }^{\star} p<0.05,{ }^{\star \star} p<0.01,{ }^{\star \star \star} p<0.001$. Difference between groups: tp $<0.01$

\section{Discussion}

This study found a progressive deterioration in respiratory function during long term $\beta$ blockade in patients with no history of reversible airways disease. This phenomenon was most pronounced with propranolol, which had a significantly greater effect on $\mathrm{FEV}_{1}$ than pindolol. In addition, FVC became progressively smaller during treatment with propranolol, but did not change during treatment with pindolol. There was no significant difference in an individual patient's response to each $\beta$ blocker according to basal values of $\mathrm{FEV}_{1}$ and $\mathrm{FVC}$, propranolol having a consistently detrimental effect while pindolol caused only small reductions in $\mathrm{FEV}_{1}$ and $\mathrm{FEV}_{1}: \mathrm{FVC}$.

Although propranolol caused a progressive and highly significant reduction in $\mathrm{FEV}_{1}$ (table III), it is not clear whether a reduction of $240 \mathrm{ml}$ in $\mathrm{FEV}_{1}$ (at 52 weeks) is clinically important as none of the patients reported increasing breathlessness or wheeze with this drug. It is also possible that the deterioration in respiratory function might progress beyond one year in a cumulative fashion, resulting in a worsening of symptoms. This effect of long term oral administration of propranolol in patients with chronic obstructive airways disease would probably result in symptomatic deterioration in pulmonary function in patients who did not initially have symptoms. Though the drug did not cause a rapid and dramatic clinical exacerbation in our patients, it did cause a definite and sustained increase in airways obstruction compared with pindolol.

The significantly greater deterioration in variables of respiratory function presumed to reflect changes in large airway calibre that we found with propranolol compared with an agent with intrinsic sympathomimetic activity has been mentioned previously. ${ }^{22}$ Patakas

Weeks after start of treatment

\begin{tabular}{|c|c|c|c|c|c|c|}
\hline & \multirow[b]{2}{*}{ Basal } & \multicolumn{5}{|c|}{ Weeks after start of treatment } \\
\hline & & 2 & 6 & 12 & 26 & 52 \\
\hline \multicolumn{7}{|c|}{ Patients treated with pindolol } \\
\hline $\mathrm{FEV}_{1}(\mathrm{l})$ & $3.16(0.830)$ & $3.11 \quad(0.824)$ & $3.11(0.831)$ & $3.06(0.832)$ & $3.07(0.826)$ & $3.04(0.782)^{\star}$ \\
\hline $\mathrm{FEV}_{1}$ (\% predicted) & $89.5(19.01)$ & $87.5(18.80)$ & $87 \cdot 7(18.45)$ & $86.4(19 \cdot 43)$ & $86.8(18.89)$ & $85.6(17.88)^{\star \star}$ \\
\hline FVC (1) & $4.6 \quad(0.819)$ & $4.6 \quad(0.876)$ & $4.66(0.875)$ & $4.59(0.856)$ & $4.6 \quad(0.860)$ & $4.6 \quad(0.874)$ \\
\hline FVC (\% predicted) & $100 \cdot 7(14 \cdot 16)$ & $99.5(13.90)$ & $101.7(12.92)$ & $100 \cdot 3(14 \cdot 74)$ & $100.5(14.08)$ & $100.5(14.75)$ \\
\hline $\mathrm{FEV}_{1}: \mathrm{FVC}$ & $68 \cdot 1 \quad(9 \cdot 79)$ & $67.6 \quad(8.92)$ & $67 \cdot 2 \quad(9.06)$ & $67 \cdot 0 \quad(9 \cdot 36)$ & $66.9 \quad(9 \cdot 50)$ & $66 \cdot 7 \quad(9 \cdot 29)$ \\
\hline \multicolumn{7}{|c|}{ Patients treated with propranolol } \\
\hline $\mathrm{FEV}_{1}(1)$ & $3.07(0.585)$ & $2.93(0.590)^{\star}$ & $2.9(0.579)^{\star}$ & $2.87(0.579)^{\star \star \star}$ & $2.86(0.570)^{\star \star}$ & $2.88(0.612)^{\star \star \star}$ \\
\hline $\mathrm{FEV}_{1}(\%$ predicted $)$ & $87 \cdot 1(14 \cdot 84)$ & $83.5(14.40)$ & $82.4(14.98)^{\star \star}$ & $81.6(14.89) \star \star \star$ & $81.6(14.44) \star \star \star$ & $80.6(14.98)$ * \\
\hline FVC (I) & $4.42(0.717)$ & $4 \cdot 37(0.746)$ & $4.38(0.776)$ & $4.31(0.739)$ & $4.27(0.766)$ & $4.23(0.772)^{\star}$ \\
\hline FVC (\% predicted) & $97 \cdot 9(14 \cdot 10)$ & $96 \cdot 6(14 \cdot 20)$ & $97 \cdot 0(14 \cdot 78)$ & $95 \cdot 3(14 \cdot 31)$ & $94 \cdot 4(13 \cdot 41)$ & $93.5(13.58)$ * \\
\hline $\mathrm{FEV}_{1}: \mathrm{FVC}$ & $67 \cdot 1 \quad(9.02)$ & $67 \cdot 1 \quad(8 \cdot 79)$ & $67 \cdot 0 \quad(8 \cdot 70)$ & $66.9 \quad(8.56)$ & $67.0 \quad(8.61)$ & $66 \cdot 8 \quad(7 \cdot 67)$ \\
\hline
\end{tabular}

$\mathrm{FEV}_{1}=$ Forced expiratory volume in one second. FVC $=$ Forced vital capacity. ${ }^{\star} \mathrm{p}<0.05,{ }^{\star \star} \mathrm{p}<0.01,{ }^{\star \star \star} \mathrm{p}<0.001$ compared with basal values. 
TABLE IV-Mean $(S D)$ results of respiratory function tests classified according to basal value of $F E V_{1}: F V C$

\begin{tabular}{|c|c|c|c|c|c|c|c|}
\hline & & \multirow[b]{2}{*}{ Basal } & \multicolumn{5}{|c|}{ Weeks after start of treatment } \\
\hline & & & 2 & 6 & 12 & 26 & 52 \\
\hline \multicolumn{8}{|c|}{ Pindolol group } \\
\hline $\mathrm{FEV}_{1}: \mathrm{FVC} \geqslant 70 \%$ & $\left\{\begin{array}{l}\mathrm{FEV}_{1}(1) \\
\mathrm{FEV}_{1}(\% \text { predicted }) \\
\mathrm{FEV}_{1}: \mathrm{FVC}\end{array}\right.$ & $\begin{array}{cc}3.73 & (0.56) \\
101.4 & (13.35) \\
76.7 & (3.62)\end{array}$ & $\begin{array}{cc}3.71 & (0.57) \\
99.9 & (15.47) \\
73.6 & (4.22)\end{array}$ & $\begin{array}{rr}3.67 & (0.63) \\
98.6 & (15 \cdot 12) \\
74 \cdot 1 & (3.92)\end{array}$ & $\begin{array}{cc}3 \cdot 64 & (0 \cdot 66) \\
98 \cdot 0 & (18 \cdot 10) \\
75 \cdot 7 \quad(4 \cdot 11)\end{array}$ & $\begin{array}{lr}3.65 & (0.55) \\
98.1 & (12.55) \\
75.0 & (3.31)\end{array}$ & $\begin{array}{l}3.54(0.58)^{\star} \\
95 \cdot 3(14 \cdot 08) \\
72 \cdot 3 \quad(2 \cdot 78)^{\star}\end{array}$ \\
\hline $\mathrm{FEV}_{1}: \mathrm{FVC}<70 \%$ & $\left\{\begin{array}{l}\mathrm{FEV}_{1}(\mathrm{l}) \\
\mathrm{FEV}_{1}(\% \text { predicted }) \\
\mathrm{FEV}_{1}: \mathrm{FVC}\end{array}\right.$ & $\begin{array}{cc}2 \cdot 63 & (0 \cdot 662) \\
78 \cdot 8 & (17 \cdot 19) \\
60 \cdot 4 \quad(6 \cdot 28)\end{array}$ & $\begin{array}{lc}2 \cdot 57 & (0 \cdot 620) \\
76 \cdot 4 & (14 \cdot 24) \\
61 \cdot 1 & (6 \cdot 06)\end{array}$ & $\begin{array}{cc}2.61 & (0.665) \\
77 \cdot 9 & (15 \cdot 87) \\
59 \cdot 4 & (7 \cdot 32)\end{array}$ & $\begin{array}{cc}2.58 & (0.619) \\
75.9 & (14 \cdot 43) \\
58.6 \quad(8.08)\end{array}$ & $\begin{array}{cc}2.55 & (0.677) \\
76.2 & (15.93) \\
59.6 & (8.08)\end{array}$ & $\begin{array}{cc}2.58 & (0.663) \\
77.0 & (16.94) \\
59.4 \quad(6.57)\end{array}$ \\
\hline \multicolumn{8}{|c|}{ Propranolol group } \\
\hline $\mathrm{FEV}_{1}: \mathrm{FVC} \geqslant 70 \%$ & $\left\{\begin{array}{l}\mathrm{FEV}_{1}(\mathrm{l}) \\
\mathrm{FEV}_{1}(\% \text { predicted }) \\
\mathrm{FEV}_{1}: \mathrm{FVC}\end{array}\right.$ & $\begin{array}{cc}3.35 & (0.47) \\
93.0 & (10.70) \\
75.1 & (3.98)\end{array}$ & $\begin{array}{c}3.19(0.58) \star \\
88.3(12.70)^{\star} \\
71.8 \quad(4.34)^{\star}\end{array}$ & $\begin{array}{l}3.18(0.52)^{\star} \\
88.6 \quad(12 \cdot 49)^{\star} \\
72 \cdot 0 \quad(5 \cdot 73)^{\star}\end{array}$ & $\begin{array}{c}3 \cdot 13(0 \cdot 49) \\
86 \cdot 9(12 \cdot 49)^{\star \star} \\
72 \cdot 1 \quad(4 \cdot 61)^{\star}\end{array}$ & $\begin{array}{rr}3 \cdot 21 & (0.49) \\
89 \cdot 3 & (10 \cdot 42) \\
72.6 \quad(4.96)\end{array}$ & $\begin{array}{l}3.14(0.52)^{\star \star} \\
87.8(11.41)^{\star \star} \\
71.5 \quad(5.02)\end{array}$ \\
\hline $\mathrm{FEV}_{1}: \mathrm{FVC}<70 \%$ & $\left\{\begin{array}{l}\mathrm{FEV}_{1}(\mathrm{l}) \\
\mathrm{FEV}_{1}(\% \text { predicted }) \\
\mathrm{FEV}_{1}: \mathrm{FVC}\end{array}\right.$ & $\begin{array}{cc}2 \cdot 82 & (0 \cdot 582) \\
81 \cdot 6 & (16 \cdot 42) \\
64 \cdot 4 & (5 \cdot 16)\end{array}$ & $\begin{array}{cc}2 \cdot 71 & (0.526) \\
79 \cdot 2 & (15 \cdot 03) \\
63 \cdot 1 \quad(7.99)\end{array}$ & $\begin{array}{cc}2.63 & (0.559)^{\star} \\
76.7 & (15.33)^{\star} \\
60.8 & (6.01)^{\star}\end{array}$ & $\begin{array}{c}2.63(0.567)^{\star} \\
76 \cdot 7 \quad(16 \cdot 19)^{\star} \\
61.5 \quad(5 \cdot 78)\end{array}$ & $\begin{array}{c}2.54(0.445)^{\star} \\
74.7 \\
62.8 \quad(14.41)^{\star} \\
(9.91)\end{array}$ & $\begin{array}{c}2.54(0.564)^{\star} \\
74.0 \\
62.5 \quad(15 \cdot 25)^{\star} \\
(7.20)\end{array}$ \\
\hline
\end{tabular}

$\mathrm{FEV}_{1}=$ Forced expiratory volume in one second. $\mathrm{FVC}=$ Forced vital capacity

${ }^{\star} \mathrm{p}<0.05 ;{ }^{\star \star} \mathrm{p}<0.01$ compared with basal values.

et al, however, when studying respiratory function after single oral doses of propranolol $(40 \mathrm{mg})$ and pindolol $(2.5 \mathrm{mg})$ in asthmatic patients, confirmed that propranolol has a bronchoconstrictive effect on large and small airways but found that pindolol, although it did not have a significant effect on large airway calibre, caused a significant bronchoconstriction of the small airways. ${ }^{23}$ They suggested that pindolol remains potentially dangerous in asthmatic patients because of this effect on small airways.

Most previous studies have examined the effect of single oral or intravenous doses of $\beta$ blockers, usually in patients with reversible airways obstruction. Studies evaluating the effect of $\beta$ blockers on respiratory function in patients receiving long term treatment for hypertension or angina pectoris are rare. Several studies have examined exclusively non-selective agents without intrinsic sympathomimetic activity. Two such studies of intravenous propranolol found an increase in airways resistance after only a few minutes. ${ }^{1024}$ The consensus is that these agents result in a predictable deterioration in respiratory function in the short term. ${ }^{25} 26$

Several studies have evaluated the role of intrinsic sympathomimetic activity on respiratory function. Benson et al carried out an acute study in 12 asthmatic subjects who received placebo, propranolol (100 mg), pindolol (5 mg), acebutolol (300 mg), and atenolol $(100 \mathrm{mg})$ and showed that propranolol caused the greatest reduction in $\mathrm{FEV}_{1} \cdot{ }^{27}$ Others have confirmed the benefit of intrinsic sympathomimetic activity. ${ }^{28}$ One disadvantage of agents with intrinsic sympathomimetic activity compared with cardioselective drugs was shown in a study of the effect of metoprolol and acebutolol on eight asthmatic subjects. ${ }^{29} \mathrm{FEV}_{\mathrm{I}}$ and peak expiratory flow rate were reduced significantly by both drugs, but after an infusion of terbutaline a dose dependent increase in the two variables occurred, although the increase was partly inhibited by acebutolol compared with atenolol. Thus if airways obstruction does occur it is less likely to be reversed by a $\beta_{2}$ agonist if the $\beta$ blocker is not relatively $\beta_{1}$ selective.

Thus there is agreement that non-selective agents without intrinsic sympathomimetic activity cause potentially harmful changes in respiratory function in patients with asthma and possibly also in those with irreversible chronic obstructive airways disease and even healthy subjects. Cardioselectivity tends to reduce the bronchoconstrictive effect, as does intrinsic sympathomimetic activity.

The available evidence suggests that no $\beta$ blocker is entirely safe in patients with chronic obstructive airways disease. If possible an alternative drug should first be considered. Bronchoconstriction after administration of a $\beta$ blocker is most pronounced in those with reversible bronchial obstruction. $\beta$ Blockers with intrinsic sympathomimetic activity or cardioselectivity have a less pronounced effect on pulmonary function and so should be preferred in cases in which a $\beta$ blocker is thought desirable despite the presence of respiratory impairment.

Ideally, it would be advantageous to develop a $\beta$ blocker with no adverse effects on respiratory function-that is, a completely cardioselective agent. This, however, would not be possible as it has been established that $\beta_{1}$ and $\beta_{2}$ receptors are not completely separated in different organs, as was postulated by Lands et al. ${ }^{30}$

\section{References}

1 McNeill RS. Effect of a beta adrenergic blocking agent, propranolol, on asthmatics. Lancet 1964;ii:1101-2.

2 Zaid G, Beall GN. Bronchial response to beta-adrenergic blockade. N Engl f Med 1966;275:580-4. Perks W, Chatterjee S, Croxson R, Cruikshank J. Comparison of atenolol and oxprenolol in patients with angina or hypertension and co-existent chronic airways obstruction. $\mathrm{Br} \mathcal{J}$ Clin Pharmacol 1978;5:101-6.

4 Richardson PS, Sterling GM. Effects of beta-adrenergic receptor blockade on airway conductance and lung volume of asthmatic patients. Br Med $\mathcal{F}$ 1969;iii: 143-5.

5 Fraley DS, Bruns FJ, Segel DP, Adler S. Propranolol-related bronchospasm in patients without history of asthma. South Med J 1980;73:238-40.

6 Schwartz S, Davies S, Juers JA. Life-threatening cold and exercise-induced asthma potentiated by administration of propranolol. Chest 1980;78: 100-1.

7 Jones RS. Significance of effect of beta blockade on ventilatory function in normal and asthmatic subjects. Thorax 1972;27:572-6.

8 MacDonald AG, Ingram CG, McNeill RS. Effect of propranolol on airway resistance. BrF Anaesth 967;39:919-26.

9 McNeill RS, Ingram CG. Effect of propranolol on ventilatory function. Am f Cardiol 1966;18

10 Nordstrom L, MacDonald F, Gobel F. Effects of propranolol on respiratory function and exercise tolerance in patients with chronic obstrurtive lung disease. Chest 1975;67:287-92

11 Tiuenius L, Nyberg G. Effects of alprerolol and propranolol on ventilatory function. Pharmacology Clinics 1969;2:51-7.

12 Stone DJ, Keltz H, Samortin T. The effect of beta adrenergic inhibition on respiratory gas exchange and lung function. Am Rev Respir Dis 1973;103:503-8.

13 Benson MK, Berrill WT, Cruikshank JM, Sterling GS. A comparison of four beta adrenoceptor antagonists in patients with asthma. Br $\mathcal{X}$ Clin Pharmacol 1978;5:415-9.

14 Decalmer PBS, Chatterjee SS, Cruikshank JM, Benson MK, Sterling GM. Beta blockers and asthma. Br Heart f 1978;40:184-9.

15 Astrom $H$, Vallin $M$. Effect of a new beta adrenergic blocking agent, ICI 66082 , on exercise haemodynamics and airway resistance on angina pectoris. Br Heart f 1974;36:1194-200.

16 Simpson W'. Nature and incidence of unwanted effects with atenolol. Postgrad Med $\mathcal{f}$ 1977;53 (suppl 3):162-7.

17 Hansson L, Henningsen NC, Karlberg BE, et al. Long-term trial of atenolol in hypertension. Curr Ther Res 1977;22:839-45.

$18 \mathrm{McDevitt}$ DG. $\beta$-adrenoceptor antagonist and respiratory function. $\mathrm{Br} \mathrm{J}$ Clin Pharmacol 978;5:97-9.

19 Paterson JW, Conolly ME, Dollery CT, Haynes A, Cooper RG. The pharmacodynamics and metabolism of propranolol in man. Eur f Clin Pharmacol 1970;2:127-33.

20 Uliah MI, Cuddihy V, Saunders KB, Addis CJ. How many blows make an FEV, FVC or PEFR? Thoro $x$ 1983;38:113-8.

21 Kambureff $\mathrm{PL}$, Woitowitz $\mathrm{HJ}$. Nomograms of an industrial population. Respiratory News Bulletin 1973;17:9-13.

2. Conolly ME, Kersting F, Dollery CT. The clinical pharmacology of beta adrenoreceptor blocking drugs. Prog Cardiovasc Dis 1976;19:203-28.

23 Patakas D, Argiropoulou V, Louridas G, Tsara V. Beta blockers in bronchial asthma: effect of propranolol and pindolol on large and small airways. Thorax 1983;38:108-12.

24 Ryo UY, Townley RG. Comparison of respiratory and cardiovascular effects of isoproterenol, propranolol and practolol in asthmatic and normal subjects. J Allergy Clin Immunol 1976;57: propran.

25 Kumana CR, Ruffin R. Application of "flow-volume curves" to assess the selectivity of P.-adrenoreceptor antagonist drugs. Br 7 Clin Pharmacol 1978;5:530-4.

26 Horvath J, Woolcock A, Tiller D, Caterson R. The effects of metoprolol and propranolol on hypertension and respiratory function in patients with hypertension and normal lung function Aust NZ J Med 1977;7:445-6.

27 Benson MK, Berrill WT, Sterling GM, et al. Cardioselective and non-cardioselective beta blockers in reversible obstructive airways disease. Postgrad Med $\mathcal{F}$ 1977;53:143-8.

28 England JDF. Beta adrenoceptor blocking drugs once daily in essential hypertension: comparison of propranolol, pindolol and atenolol. Aust NZ J Med 1981;11:35-40.

29 Greefhorst APM, Van Herwaarden CLA. Ventilatory and haemodynamic effects of terbutaline

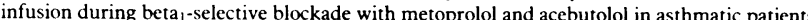
Eur $\mathcal{X}$ Clin Pharmacol 1982;23:203-8.

30 Lands AM, Arnold A, McAuliff JP, Luduena FP, Brown TG. Differentiation of receptor systems estimated by sympathomimetic amines. Nature 1967;214:597-8.

(Accepted 6 May 1986) 